\title{
МИФ, МИРОВОЕ ВРЕМЯ И МОДЕЛИ ПРОСТРАНСТВА В ПОСТМОДЕРНИСТСКИХ ПРОИЗВЕДЕНИЯХ В. ПЕЛЕВИНА ${ }^{1}$
}

\author{
Josef Dohnal ${ }^{2}$, Assel Abaganova ${ }^{3}$ \\ (Masarykova univerzita; Trnavská univerzita v Trnave) \\ (Евразийский университет имени Л.Н. Гумилева)
}

\begin{abstract}
Ключевые слова постмодернизм, миф, мифопоэтика, мифотворчество, вампирская мифология, модели пространства, архетип Keywords: postmodernism, myth, mythopoetics, myth-making, vampire mythology, space models, archetype
\end{abstract}

\begin{abstract}
Аннотация: Josef Dohnal, Assel Abaganova. MYTH, WORLD TIME AND SPACE MODELS IN THE POSTMODERN WORKS OF V. PELEVIN. "PORÓWNANIA" 2 (23), 2018. Vol. XXIII, P. 151-172. ISSN 1733-165X. В данной статье рассматривается одна из тем творчества Виктора Пелевина - миф. Исследуется миф с учетом всех его форм, вариаций и трансформаций от классической мифологии (Бог Ра), современной социальной, политической до вампирской мифологии. Миф, в силу тематизированной возможности многократной повторяемости, модифицирует категорию времени в развертывании сюжета в произведениях постмодернистов. В статье изучается проблема определения статуса и роли мифа в творчестве В. Пелевина. Делается вывод о том, что миф является фундаментальной категорией многих романов Пелевина. Писатель использует в романах такую особенность своей поэтики, как «неомифологизм» - межтекстовое заимствование некоторых элементов архаических структур мифов или мета-историй. Объективное историческое время заменяется мифологическим временем, поскольку действия и события представлены в романе как прототипы.
\end{abstract}

Abstract: Josef Dohnal, Assel Abaganova. MYTH, WORLD TIME AND SPACE MODELS IN THE POSTMODERN WORKS OF V. PELEVIN. "PORÓWNANIA" 2 (23), 2018. Vol. XXIII, P. 151-172. ISSN 1733-165X. This article focuses on one of the themes of Pelevin's creative work -

1 Статья написана в рамках выполнения гранта KEGA 013UCM-4/2017 Vymedzovanie špecifík modelu „ruského sveta“ v ruskom jazyku, literatúre a kultúre.

2 E-mail: jdohnal@phil.muni.cz

3 E-mail: abaganova.a@list.ru 
the category of myth. The myth is investigated in all its forms, variations and transformations from classical mythology (God Ra) to modern social, political to vampire mythology. Modern mythology is an instrument of socialization of a mass man, and manipulation of his consciousness. Myth, by virtue of many times repeated frequency, changes the category of time in the unfolding of the plot in the works of postmodernists. The problem of determining the status and role of myth in the work of V. Pelevin is studied. Pelevin uses in his novels such a feature of his poetics as «neomythologism» - the intertextual borrowing of certain elements of archaic structures of myths or meta-stories. Mythological time replaces the objective historical time, since actions and events are represented as prototypes in the novel.

Постмодернизм - явление, которое в качестве более широкого литературного направления первоначально появилось и теоретически осмыслилось в западном искусстве. Предпосылки к возникновению нового подхода к литературной деятельности и изображению мира, названные позже постмодернистскими, были связаны с трансформациями, наблюдаемыми отчасти в предыдущей литературно-исторической эпохе - в модерне. Уже в произведениях писателей-модернистов начала XX века, таких как Джеймс Джойс, Франц Кафка, Марсель Пруст, Андрей Белый и др., можно наблюдать возникновение нового типа ментальности, соответствующей восприятию внутреннего и внешнего мира человека на рубеже (и за рубежом) эпох, для которых характерна ломка ценностных установок, резкая смена идеологий и технологий, изменения в сфере общественного строя, определенная «текучесть» всего, что раньше было более прочным и что определяло большую уверенность индивида в жизненном мире и в себе самом, в своей позиции в мире. Восприятие такого комплексного сдвига не могло не отразиться в искусстве, в частности, в литературе - рефлексия этих изменений в индивидуальном и социальном мировоззрении постепенно влияет и на возникновение нового типа литературы.

В изменяющихся условиях, в обстановке все время (де)формирующихся ценностей и сомнений в целостности, прочности и определенности реальности, миф стал тем потенциально гармонизирующим центром, содержащим вечные и по своей сути неизменные ценности, потенциальной опорой в трансформирующемся мире.

Лексема «миф» имеет несколько значений и основных смыслов. Часто используется в значении «выдумка», «обман», обозначает также понятие «легенда», «сказание», служит и для обозначения гармоничного, синкретичного мировоззрения, характерного для первобытного человечества (Савельева 1). С историко-культурологической точки зрения понятие «миф» трактуется как «форма общественного сознания, возникшая в условиях сравнительно низкого уровня социального развития и отражающая в виде образного повествования фантастические представления о природе, обществе и личности» (Бубенцова 6). К.Г. Юнг описывает миф как «знание, разомкнутое в беско- 
нечность...» (Юнг 11). А.Ф. Лосев считал, что миф - это чудо, раскрывающее тайну человеческой личности, «миф есть развернутое магическое имя» (Лосев 167). Именно такое счастливое переживание слияния реальной жизни и идеала, по мнению Лосева, и заключено в мифе. Е.М. Мелетинский говорит о том, что «миф - первичная модель всякой идеологии и синкретическая колыбель различных видов культуры - литературы, искусства, религии и, в известной мере, философии и даже науки» (Мелетинский 175).

Стеблин-Каменский в своей работе так высказывается о мифе: «миф это повествование, которое там, где оно возникало и бытовало, принималось за правду, как бы оно ни было неправдоподобно» (Стеблин-Каменский 1). Он предлагает учесть историю изучения мифологии Яна де Фриса «Forschungsgeschichte der Mythologie», говоря о данном исследовании как об антологии высказываний о мифах, которые способствуют созданию точной картины изучения мифологии. Эти исследования могут дать, по его мнению, объективную историю изучения мифов. (Стеблин-Каменский 4).

На наш взгляд, постмодернизм, стремясь переделать, переосмыслить классическую традицию, трансформирует понятие мифа, но в целом не уходит от традиционного взгляда на мир, как будто принимая его за основной стержень и в литературных произведениях. В последние десятилетия, с одной стороны, культура в целом выражает свой собственный «мифос», формирует под новую идеологию мифологическое пространство, характеризующееся новым пониманием мира и места человека в нем. А с другой стороны, она пытается найти что-то прочное, что не является сиюминутным, на что можно всегда опереться, от чего можно оттолкнуться в своем дальнейшем развитии - в русской литературе это наступает именно после крушения бывших «прочных основ» вроде марксизма. Миф как особый способ образно-символического выражения мировоззрения, характерного для определенной культуры, оказывается формой, не ушедшей безвозвратно в прошлое. В нем обнаруживается некая константа, сохраняющаяся в человеческом сознании на протяжении всей жизни и человека, и человечества, подобно тому, как в процессе индивидуального развития неизменным остается генотип, хотя физически и внешне человек меняется до неузнаваемости.

У модернистов миф выступает, по определению М. Бахтина, как «память жанра» (Бахтин 83) или как поддержка социального и природного порядка (Мелетинский 59) в эпоху распада ценностей и хаоса в обществе. Это понимание мифа в изучении данного вопроса близко нам. Следуя ему, можно предположить, что существует определенная прочная, «вечная», т.е. повторяющаяся в своих разных проявлениях, основа мироздания, что позволяет повторять парадигму ее отображения как в сознании разных поколений, которые ее и живут, и ищут в своем мироосмыслении, так и в произведениях искусства, рефлектирующих это сознание. Подобное взаимопроникновение мотив- 
но-образных парадигм разных культурно-исторических эпох в литературе не ново. Оно обусловливается их параллелизмом, схожими по своим основным качествам картинами мира. Можно вспомнить теорию первичных и вторичных систем (стилей) (Смирнов 2).

Концептуальное изменение модели представляемого литературными произведениями мира повлияло на их поэтику. Приближаясь к мифу, текст воспроизводил и заново актуализировал фундаментальные основы человеческого существования и бытия вообще и искал для этого подходящие средства. Прием мифологизирования предполагал вовлечение в ткань произведения циклической ритуально-мифологической повторяемости для выражения архетипов и конструирование повествования так же, как и образов, в качестве архетипальных, с точки зрения повествования вызвал актуализацию структур прошлого в современном мире и обращение к всепроникающей «психологизации». Начиная с 1920-х гг., то есть со времени расцвета модернизма в литературе, многие художественные тексты прямо или косвенно строятся на использовании мифа, например, «Волшебная гора» Т. Манна - на мифе о певце Тангейзере, который провел семь лет на волшебной горе богини Венеры, «Шум и ярость» У. Фолкнера - на евангельской мифологии.

Причинами развития неомифологического сознания в конце XX века в русской среде, первые «сигналы» которого можно наблюдать уже в 60-70е годы, мы можем обозначить некий комплекс социально-психологических сдвигов, включающих множество факторов разного уровня, полный перечень которых вряд ли можно дать. Такие, например, как распад СССР, отказ от оказавшегося иллюзией единого типового общественного сознания, утрата доверия ко всем идеологическим постулатам, навязываемым режимом, ощущение мирового кризиса, связанного отчасти с ожиданием конца света под самый конец XX века, активизация религиозных пластов сознания и иное (Земсков 32), сказалось, наверное, и влияние «магического реализма», исходящего из подобных сдвигов в общественном сознании, только в другой среде. Появление неомифологизма становится характерным для романов, создаваемых в традициях поэтики русского постмодернизма (Топоров 229), но оно намечается чуть раньше - достаточно вспомнить некоторые произведения, напр. «Плаха» Ч. Айтматова или «Белка» и «Отец Лес» А. Кима.

Включение мифа в произведения постмодернистов, в силу ему присущей идеи многократной повторяемости, влияет на категорию времени в развертывании сюжета. Архетипические события происходили в прошлом, происходят в настоящем и будут происходить в будущем даже при внешне измененных обстоятельствах; благодаря этому они выглядят с точки зрения их сути неизменными, а акцент переносится с хронологической последовательности на изображение «застывших» моделей, ситуаций, с повествования - на иллюстрацию, проецирование. 


\section{В.Н. Топоров пишет:}

«В мифопоэтическом хронотопе время сгущается и становится формой пространства (как бы выводится вовне, откладывается, экстенсифицируется), его новым («четвертым») измерением» (Топоров 229).

Постмодернизм разрушил такую фундаментальную черту (характерную не только для русской культурной традиции), как преобладание дуальных моделей. Результатом этого, как и результатом симуляции всеобщего единства, стало слияние в текстах «высокого» и «низкого», «трагического» и «комического», канона высокой реалистической классики и фикции, христианской (и не только) традиции и язычества, фантастики и похожих, связанных с реальностью, конструированных образов, смешение времени и пространства.

Исследуя роман Виктора Пелевина «Омон Ра», мы заметили, что объектом внимания повествователя становится, как называет это Ф. Джеймсон, «политическое бессознательное» (Джеймсон 116) позднесоветской эпохи, направленность ее мифологии на гармоничность существования советского социума. Эта направленность мифологии («бессознательного») на «снятие противоречий» в советском социуме постоянно подчеркивается повествователем в романе «Омон Ра»:

«- Это фрагмент лунной поверхности», - сказал начальник полета. - Как ты знаешь, Омон, наша космическая наука преимущественно исследует обратную сторону Луны, в отличие от приземляющихся на дневной стороне американцев. Вот эта длинная полоса - так называемая трещина имени Ленина, открытая несколько лет назад отечественным спутником. Это уникальное геологическое образование, в район которого в прошлом году была отправлена автоматическая экспедиция по получению образцов лунного грунта. По предварительным результатам исследований сложилось мнение о необходимости дальнейшего изучения трещины. Тебе, наверно, известно, что наша космическая программа ориентирована в основном на автоматические средства - это американцы рискуют человеческими жизнями. Мы подвергаем опасности только механизмы. И вот возникла мысль об отправке специального самоходного транспортного средства, так называемого лунохода, который проедет по дну трещины и передаст на Землю научную информацию. Начальник полета открыл ящик стола и, не отводя от меня глаз, стал шарить там рукой. - Общая длина трещины - сто пятьдесят километров, а ширина и глубина крайне незначительны и измеряются метрами. Предполагается, что луноход проедет по ней семьдесят километров - на столько должно хватить энергии в аккумуляторах - и установит в ее центре вымпел-радиобуй, который передаст в космос преобразованные в радиоимпульсы слова «МИР», «ЛЕНИН» и «СССР» (Пелевин, 1, 24). 
«- Неужели все это правда? - тихо спросил Митёк. Я пожал плечами. Я не знал, что именно он имеет в виду. «- Ладно, насчет авиации я поверить еще могу», - сказал он. - Но вот насчет атомного оружия... Допустим, в сорок седьмом еще можно было заставить подпрыгнуть два миллиона политзаключенных. Но сейчас-то их у нас нет, а атомное оружие ведь каждый месяц...» (Пелевин, 1, 31).

Если взять древнеегипетскую мифологию, на которую явно опирался Пелевин, то можно отметить бога Амона, члена фиванской Огдоады («Восьмерицы богов»). Его культ, вероятно, шел от Амаунета, древнейшего божественного покровителя Фив. Амон тоже был богом-творцом, создававшим все при помощи дыхания, и поначалу больше ассоциировался с ветром, а не с солнцем. С течением времени Амон стал почитаться в Верхнем (Южном) Египте так же сильно, как Ра в Нижнем (Северном). В конце концов их объединили в образе Амона-Ра, солнечного бога-творца. Трудно установить, когда впервые возникло это сочетание, но ссылки на Амона-Ра имеются уже в текстах пирамид начала $\mathrm{V}$ династии фараонов. Новое царство возникло как итог борьбы за объединение Египта с юга, и правители XVIII династии стали поддерживать культ Амона-Ра, чтобы объединить южного Амона с прежними верованиями в Ра. Амон-Ра получил официальный титул «царя богов», и изображался в виде человека с красными глазами и головой льва или сокола, окруженной солнечным диском и обвитый змеей (Солкин 478).

Пелевин, вероятно, не случайно именно так называет свой роман, в котором все люди поклоняются тоталитарной системе, существовавшей в Советском Союзе. В самом произведении он делает отсылку к этому факту прошлого, высмеивая установленный режим и систему, незначительность личности в условиях (любой) тоталитарной системы. Он указывает на то, что личность со всем ее разнообразным внутренним миром - лишь повод для «системообразующих» людей получить себе очередную звездочку на погонах или удовлетворение собственного тщеславия, именуемого принципами. Автор использует в романе «Омон Ра» аббревиатуру «ОМОН» - «Отряд милиции особого назначения», показывая ту силу, которая обеспечивает соблюдение мифа, которая, возможно, олицетворяет мифологические представления советского человека о сущности имени и влиянии его на судьбу:

«Омон - имя не особо частое и, может, не самое лучшее, какое бывает. Меня так назвал отец, который всю свою жизнь проработал в милиции и хотел, чтобы я тоже стал милиционером» (Пелевин, 1, 1).

Он также дает такое имя главному герою - Омон, изменяя лишь первую букву имени. И тут же в романе появляется намек на древнеегипетскую ми- 
фологию, когда герой берет своим позывным именем слово Ра, получаемое в совокупности Омон Ра:

«Твой позывной, как ты и просил, „Ра”. Трудно было, - начальник полета многозначительно ткнул пальцем вверх, - но отстояли. Только ты там, - он ткнул пальцем вниз, - пока ничего не говори» (Пелевин, 1, 90).

Автор сравнивает бескомпромиссное поклонение людей богу с таким же бессмысленным поклонением идеологии коммунизма, когда в обоих случаях человеческое жертвоприношение было просто способом для видимого улучшения жизни, когда животных стали заменять людьми. Это также жертва, которую автор иронично называет в «Омон Ра» подвигом:

«Ивану Трофимовичу дали бронежилет, каску и кабанью шкуру, и началась новая работа - такая, которую смело можно назвать ежедневным подвигом. В первые дни ему было немного страшно, особенно за открытые ноги, но потом он пообвыкся, да и члены правительства, знавшие, в чем дело, старались целить в бок, где был бронежилет, под который Иван Трофимович для мягкости подкладывал думку. Иногда, конечно, какой-нибудь дряхленький ветеран ЦК промахивался, и Иван Трофимович надолго попадал на бюллетень - там он прочел много книг, в том числе и свою любимую, воспоминания Покрышкина. Какой это был опасный под стать ратному - труд, ясно хотя бы из того, что Ивану Трофимовичу каждую неделю меняли пробитый пулями партбилет, который он носил во внутреннем кармане шкуры. В дни, когда он бывал ранен, вахту несли другие егеря, в числе которых был и его сын Марат, но все же опытнейшим работником считался Иван Трофимович, которому и доверяли самые ответственные дела, иногда даже придерживая в запасных, если охотиться приезжал какой-нибудь небольшой обком (Иван Трофимович каждый раз оскорблялся, совсем как Покрышкин, которому не давали летать с собственным полком). Ивана Трофимовича берегли. Они с сыном тем временем изучали повадки и голоса диких обитателей леса - медведей, волков и кабанов - и повышали свое мастерство» (Пелевин, 1, 87).

Развенчание мифа о советской космонавтике в романе «Омон Ра» и мироощущение буддизма, которым пропитано все произведение, позволяет утверждать наличие некоей дидактической задачи автора. Повествуемое время противопоставляется «вечности» мифа, показывая, что эфемерное появление и принятие/непринятие «новой идеологии», иной жизни в ином теле, по сути лишь повторяющийся цикл того, что уже было когда-то.

Главный герой начинает осознавать, что навязываемое ему представление о светлом будущем современного общества является мифом: 
«Единственным пространством, где летали звездолеты коммунистического будущего... было сознание советского человека, точно так же, как столовая вокруг нас была тем космосом, куда жившие в прошлую смену запустили свои корабли, чтобы те бороздили простор времени над обеденными столами, когда самих создателей картонного флота уже не будет рядом. Главное, что должно было отличать эти бутафорские аппараты - множество блестящей фольги, густо написанное «СССР», красные звезды, - и вот уже для ребенка само слово «звездолет» «связано с красными звездами на бортах советской космической техники» (Пелевин, 1, 73).

Пелевин использует в своих произведениях перспективный текст и структурирует роман с опорой на современное происхождение текста - создает метарассказ о советском мифе, преувеличивая некоторые его элементы. Это было необходимо для того, чтобы в сложившийся предметный мир поместить главного героя, который почти бессознательно совершает путь личного совершенствования, поднимаясь «над мифом» и в конце отказываясь соучаствовать в его порождении, что можно отметить в тексте произведения «Омон Ра»:

\begin{abstract}
«Откинув крючок, я потянул планшет на себя. Открылся квадрат стены, в центре которого был выключатель, выкрашенный золотой краской. Чувствуя, как у меня все сильнее сосет под ложечкой, я протянул руку и перещелкнул его вверх. Раздался негромкий гудок, и я, еще не поняв, что это такое, почувствовал, что совершил с окружающим миром и самим собой что-то страшное. Гудок прозвучал опять, громче, и вдруг выяснилось, что выключатель, открытая малиновая дверца и весь коридор, где я стою, - все это ненастоящее, потому что на самом деле я вовсе не стою у стены с выключателем, а сижу в скрюченной и неудобной позе в каком-то крайне тесном месте» (Пелевин, 1, 124).
\end{abstract}

Определенные мифологические структуры, существующие ранее, в некоторых случаях вступают в отношения контаминации и образуют целые комплексы мифологем, изначально представляющих из себя самостоятельные мифы. Пелевин отсылает к целостному впечатлению от мифов, формирующемуся у персонажа либо у читателя. Использование мифов проявляется в произведениях как прямым заимствованием конкретных сюжетов архаичных мифологий, так и использованием мифологических мотивов и параллелизма, создавая таким образом «вторичный миф», заведомо «сконструированный» писателем.

Такое свойство главного героя, ставшее признанием собственного индивидуального сознания в качестве единственной и несомненной реальности и отказом от объективной реальности окружающего мира, мы замечаем и в других романах Пелевина - «Жизнь насекомых», «Чапаев и Пустота», «Generation „П“». В них автор также вкрапляет мифы, которые помогают стабилизировать 
текст и сознание героев. Ведь, например, в романе «Жизнь насекомых» Пелевин доводит до абсурда религиозное представление буддизма в возможном переселении человеческих душ в животных, насекомых.

Подобно включению советского мифа в текст произведения, мы можем обнаружить использование буддийской мифологии в повести автора «Желтая стрела». Следует заметить, что такой мифический по своей природе пласт культурно-исторического знания, как буддистский, постоянно присутствует практически во всех произведениях писателя. Как отмечает Г.А. Сорокина:

«... буддизм стал для автора плодотворным источником образотворчества, реализованного на основе современных реалий, представлений и знаковых систем. При этом происходит сближение архаичной символики и реалий современной жизни, что следует рассматривать как яркое интересное литературное и философско-культурологическое явление» (Сорокина 337).

Влияние буддизма на искусство (Н. Рерих, Л. Бакст) и в частности на литературу конца XIX - первой половины XX века можно также отметить и в творчестве известных писателей и поэтов (Л. Толстого, И. Бунина. В. Хлебникова, К. Бальмонта и др.). Анализ влияния буддизма на литературу позволяет отчетливо представить то напряженное внимание, которое в это время было направлено на восточную культуру, увидеть диалоговую соотнесенность культур Запада и Востока, способы и формы художественного освоения буддийской культуры.

В тексте повести «Желтая стрела» приводится фрагмент из буддийской притчи об обуздании собственного сознания-слона:

«Куда они все идут? Зачем? Разве они никогда не слышат стука колес или не видят голых равнин за окнами? Им все известно про эту жизнь, но они идут дальше по коридору, из сортира в купе и из тамбура в ресторан, понемногу превращая сегодня в очередное вчера, и думают, что есть такой Бог, который их за это вознаградит или накажет... Милость беспредельна, и я точно знаю, что, когда поезд остановится, за его желтой дверью меня будет ждать белый слон, на котором я продолжу своя вечное возвращение к Неименуемому» (Пелевин, 3, 35).

Возможно, Пелевин, преломляя основы буддизма в своих романах, говорит об освобождении сознания, и поэтому включает основные положения учения буддизма, в основу которого, как известно, положены выводы Будды Шакьямуни о том, что причиной страдания людей являются они сами, их привязанность к жизни, к материальным ценностям, а также вера в неизменную душу, являющаяся попыткой создать иллюзию, противостоящую всеобщей изменчивости. Прекратить страдания (вступить в нирвану - состояние осознания 
своей души, достигаемое с помощью самоотречения, отказа от комфортных условий внешней среды) и достигнуть пробуждения, в котором жизнь видится «такой, какова она есть», можно путем разрушения привязанностей и иллюзий устойчивости с помощью практики самоограничения и медитации. В произведении изменен один из буддистских тезисов о том, что мир - это только мои впечатления. Автор же говорит о том, что эти впечатления нередко не только навязаны, но и заменены на новый стандарт мироощущения, поведения и реальности. Человек утрачивает веру в основные постулаты жизни, так как каноны веры разрушены и заменены новыми богами, новой верой. Поэтому человеческая личность становится зависимой от социума и никогда не будет свободна; этот тезис автор высказывает в произведении «Желтая стрела»:

«- Видишь ли, - печально сказал Дима, - своими недавними действиями ты растревожил одно очень могущественное существо. Ему все это ужасно не понравилось. И сейчас оно явится за тобой. - А какое ему до меня дело? - спросил Митя.

- Оно считает, что ты находишься в его полной власти. Принадлежишь ему. А то, что ты пытаешься делать, этой власти угрожает. И это существо нападет на тебя с минуты на минуту.

- Кто это? - Труп, - сказал Дима как нечто само собой разумеющееся.

- Чей труп? - Твой, - сказал Дима, - чей же еще.

- Ты хочешь сказать, что я умру? - В каком-то смысле, - ответил Дима. - Когда я говорю «труп», я имею в виду, что тебя ждет тот, кто сейчас живет вместо тебя. На мой взгляд, самое худшее, что с тобой может произойти, - это то, что он и дальше будет жить вместо тебя. А если умрет он, вместо него будешь жить ты» (Пелевин, 3, 51).

В романе Пелевина «Чапаев и Пустота» мы встречаемся с героем произведения - комиссаром Чапаевым, которым становится поэт-декадент, появившийся в современной Москве. Пелевин опирается в романе на узловые эпизоды мифа и произведений о Чапаеве, инкорпорирует их практически без изменений в свой текст, тем самым обыгрывая их. Автор создает свой миф о Чапаеве, увидев в анекдотах о легендарном красном командире аналог буддийской сутры (коан, гун-ань): диалоговая форма коана, не имеющего логического ответа, сходна с анекдотом, содержащим абсурдный ответ. Для главного героя анекдот является средством создания мифа-реальности. И в этом романе появляется отражение учений буддизма, разговор о пустоте, о вечности и бесконечности.

Одной из основных идей буддизма, его целевой установкой является путь к нирване. Согласно всем школам буддизма, нирвана - конечная цель человеческого существования, достижение которой равнозначно окончательному 
уничтожению страдания, исчерпанности притоков аффектированного сознания, прекращению трансмиграции (сансара) и действия механизмов «закона кармы» (Философская энциклопедия 1).

В романе «Чапаев и Пустота» автор включает в текст повествование о нирване и о том, как ее можно достичь:

«То, что я увидел, было подобием светящегося всеми цветами радуги потока, неизмеримо широкой реки, начинавшейся где-то в бесконечности и уходящей в такую же бесконечность. Она простиралась вокруг нашего острова во все стороны насколько хватало зрения, но все же это было не море, а именно река, поток, потому что у него было явственно заметное течение. Свет, которым он заливал нас троих, был очень ярким, но в нем не было ничего ослепляющего или страшного, потому что он в то же самое время был милостью, счастьем и любовью бесконечной силы - собственно говоря, эти три слова, опохабленные литературой и искусством, совершенно не в состоянии ничего передать. Просто глядеть на эти постоянно возникающие разноцветные огни и искры было уже достаточно, потому что все, о чем я только мог подумать или мечтать, было частью этого радужного потока, а еще точнее - этот радужный поток и был всем тем, что я только мог подумать или испытать, всем тем, что только могло быть или не быть, - и он, я это знал, наверное, не был чем-то отличным от меня. Он был мною, а я был им. Я всегда был им, и больше ничем. - Что это? - спросил я. - Ничего, - ответил Чапаев. - Да нет, я не в том смысле, - сказал я. - Как это называется? - По-разному, - ответил Чапаев. Я называю его условной рекой абсолютной любви. Если сокращенно - Урал. Мы то становимся им, то принимаем формы, но на самом деле нет ни форм, ни нас, ни даже Урала. Поэтому и говорят - мы, формы, Урал. - Но зачем мы это делаем? Чапаев пожал плечами. - Не знаю. - А если по-человечески? - спросил я. - Надо же чем-то занять себя в этой вечности, - сказал он. - Ну, вот мы и пытаемся переплыть Урал, которого на самом деле нет. Не бойся, Петька, ныряй!» (Пелевин, 4, 250).

Пустота (санскрит. «шуньята») - одно из понятий буддизма, которое Пелевин использует очень часто в своих произведениях. В проповеди Будды в Ганджуре имеется раздел «Праджняпарамита». Это учение о праджне, которая есть видение пустоты мира, или видение шуньяты. В ней говорится о том, что Абсолют (Пустота) недоступен дискурсивному методу познания, а шуньята является реальностью Абсолюта, поэтому так же находится за пределами действий человеческого разума. Но у каждого индивида есть праджня - это эмоционально-религиозная интуиция в потенциальном состоянии. Только она способна познавать трансцендентные вещи, подобные Пустоте. Праджня раскрывается в момент просветления индивида путем добродетельных поступков и строгого соблюдения правил. Эмоционально-мистическая интуиция направлена на внутренний духовный мир человека. Она постигает вещь 
вне сознания, выше его и познает единство, недвойственность, т.е. природу Абсолюта и, стало быть, саму пустоту.

В романе «Чапаев и Пустота» можно заметить, что броневик Чапаева, на котором Пустота, персонаж романа, совершает побег, неслучайно имеет щели, похожие на полузакрытые глаза Будды. И сам побег представляет собой вариацию на тему «освобождения от мира страдания». Только отказавшись от иллюзорного Я и веры в реальность мира, через просветление и полное отсутствие мыслей можно достичь нирваны. Нирвана - Ничто, Никто и Нигде Пустота. Главный герой постоянно размышляет о вопросах познания мира, своего предназначения, внутреннего Я и природы вещей, окружающих его:

«Хорошо, - сказал Чапаев, хитро прищуриваясь, - насчет «кто» мы потом поговорим. А сейчас, друг милый, давай с «где» разберемся. Скажи-ка мне, где эта манда живет? - В моем сознании. - А сознание твое где? «- Вот здесь», - сказал я, постучав себя по голове. - А голова твоя где? - На плечах. - А плечи где? - В комнате. - А где комната? - В доме. - А дом? - В России. - А Россия где? - В беде, Василий Иванович. - Ты это брось, - прикрикнул он строго. - Шутить будешь, когда командир прикажет. Говори. - Ну как где. На Земле. Мы чокнулись и выпили. А Земля где? - Во Вселенной. - А Вселенная где? Я секунду подумал. - Сама в себе. - А где эта сама в себе? - В моем сознании. - Так что же, Петька, выходит, твое сознание - в твоем сознании? - Выходит так» (Пелевин, 4, 273).

«На самом деле я думаю о другом. - О чем же? - спросил Чапаев. - О том, что человек чем-то похож на этот поезд. Он точно так же обречен вечно тащить за собой из прошлого цепь темных, страшных, неизвестно от кого доставшихся в наследство вагонов. А бессмысленный грохот этой случайной сцепки надежд, мнений и страхов он называет своей жизнью. И нет никакого способа избегнуть этой судьбы. - Ну отчего, - сказал Чапаев. - Способ есть» (Пелевин, 4, 242).

У Пелевина герой - это воплощение Будды, Просветленного. Автор создает антимиф и миф одновременно. Главный герой, Пустота, страдает раздвоением личности, причем та личность, которую врач считает ложной, для Чапаева является истинной. Раздвоение помогает герою существовать в разных мирах. Петр просыпается во второй части романа «Чапаев и Пустота» в середине 1990-х в психиатрической лечебнице, в которой главврач лечит раздвоение ложной личности по собственной новой научной методике: группу пациентов погружают в ложную реальность одного из них, а по окончании сеанса все они возвращаются к своим привычным маниям:

«Говоря по-простому, это совместная борьба больных за выздоровление. Представьте себе, что ваши проблемы на время становятся коллективными, то есть каждый из участников сеанса в течение некоторого срока разделяет ваше 
состояние. Так сказать, отождествляется с вами. Как вы думаете, к чему это приведет? Я молчал. - Очень просто, - продолжал Тимур Тимурович. - После того как сеанс заканчивается, возникает эффект отдачи - совместный выход участников из состояния, только что переживавшегося ими как реальность. Это, если хотите, использование свойственного человеку стадного чувства в медицинских целях. Те, кто участвует в сеансе вместе с вами, могут проникнуться вашими идеями и настроениями на некоторое время, но, как только сеанс кончается, они возвращаются к своим собственным маниям, оставляя вас в одиночестве. И в эту секунду - если удается достичь катарсического выхода патологического психоматериала на поверхность - пациент может сам ощутить относительность своих болезненных представлений и перестать отождествляться с ними. А от этого до выздоровления уже совсем близко» (Пелевин, 4, 167).

Внутреннюю Монголию возможно рассматривать как симулякр, созданный сознанием Петра Пустоты, некую комфортную нирвану, удовлетворяющую наконец субъекту, установившему истину о Вселенной. Довольно репрезентативной выглядит следующая версия: Пустота является пациентом психиатрической клиники, и все происходящее с ним - это лишь галлюцинации, бред, от которых герой излечивается; однако при вступлении в физический контакт с окружающим миром происходит рецидив, и галлюцинации выходят на новый, трансцендентальный уровень. Подобная относительность установленной, казалось бы, окончательной истины является определенным шагом для автора, однозначно влияющим на генезис следующего романа.

Можно отметить, что в романе возникает мифология третьего порядка, учитывающая произошедшие в массовом сознании изменения. Ее можно определить как «личное мифологизирование», один из приемов которого в соединении «криптоистории» - неправдоподобной, но в целом укладывающейся в череду известных исторических фактов - и «альтернативной истории», так как картина современного общества XX века хоть и представлена в виде бреда главного героя, однако не теряет для читателя своей актуальности (Цыганов 2).

«К творчеству В. Пелевина вполне применимы оба термина («альтернативная история» и «криптоистория») и связано это не в последнюю очередь с постоянным нарушением времени и места в романе, выходов героя в прошлое и будущее - одной из черт модернистского произведения. Мифологическое время в романе вытесняет объективное историческое время, поскольку действия и события определенного времени повторяются во времени ином, представляются в качестве воплощения вечных прототипов. Мировое время истории превращается в безвременный мир мифа, что находит выражение в пространственной форме. Время зависит от наполняющих его действий героя - а это уже ситуация мифа-сказки» (Цыганов 4). 
Исследователь говорит о присутствии криптоистории в романе Пелевина через Чапаева: он выпадает из реальной истории, «революционный период» романа так же заканчивается исчезновением Чапаева из реальности, бои чапаевской дивизии с белогвардейцами имеют место и в истории, и в романе. Фурманов, Котовский, Чапаев, Ленин, Брюсов - реальные исторические лица, однако причины поступков, сущность и поведение героев вымышлено, образы их лишены исторического правдоподобия. Альтернативная история явно в романе не присутствует, но ее законы в произведении соблюдаются: комиссаром Чапаева становится поэт-декадент, сам Чапаев появляется в современной Москве. И то, что главный герой понимает, что современная действительность - это мир Котовского, вернее, миф, им созданный, так же указывает на альтернативную историю. Принцип альтернативной истории позволяет Пелевину выстроить такую картину мира, в которой основные действующие лица оказываются нашими современниками.

Похожее раздвоение, но в мирах, можно заметить и в романе «Жизнь насекомых». Обитатели этого мира взаимодействуют друг с другом в двух равноправных телесных модусах - людей и насекомых. Каждое действие героя как насекомого немедленно отзывается в нем как в человеке. Жизнь людей-насекомых оказывается непрекращающейся взаимосогласованной симуляцией актов существования:

«Шумело море, но, когда ветер начинал дуть в сторону пансионата, можно было разобрать обрывки обращенных к пустому пляжу радиопредложений. - . . вовсе не одинаковы, не скроены по одному и тому же шаблону... - . . создал нас разными не часть ли это великого замысла, рассчитанного, в отличие от скоротечных планов человека, на многие... - . ..чего ждет от нас Господь, глядящий на нас с надеждой? Сумеем ли мы воспользоваться его даром?.. - . . он и сам не знает, как проявят себя души, посланные им на...- Действительно, - сказал Арнольд, - лучше бы завтра. И по нашим адресам. А то у вас сложится искаженное представление. - Если у меня сложится искаженное представление, у вас будет достаточно времени, чтобы его исправить, - ответил Сэм. Уверенным спортивным движением он вскочил на перила балкона и сел, свесив в пустоту ноги. Двое остальных, вместо того чтобы удержать его, влезли на ограждение сами. Артур проделал эту операцию без труда, а Арнольду она удалась только со второй попытки, и сел он не так, как первые двое, а спиной ко двору, словно для того, чтобы голова не кружилась от высоты. Вперед, - сказал Сэм и прыгнул вниз. Артур молча последовал за ним. Арнольд вздохнул и спиной вперед повалился следом, как аквалангист, опрокидывающийся в морес борта лодки. Окажись у этой сцены свидетель, он, надо полагать, перегнулся бы через перила, ожидая увидеть внизу три изувеченных тела. Но он не увидел бы там ничего, кроме восьми небольших луж, расплющенной пачки от сигарет «Приморские» и трещин на асфальте. Зато если бы он обладал нечеловечески 
острым зрением, то смог бы разглядеть вдалеке трех комаров, улетающих в сторону скрытого за деревьями поселка» (Пелевин, 2, 8).

В романе автор вносит в текст комплекс характерных, влиятельных для своего исторического контекста или, напротив, архетипичных мифем, показывает возможности и пути их восприятия, механизмы генезиса, особенности их бытования, образ зависимости большинства обладателей антропологического сознания именно от данных мифем. Композиция текста «Жизнь насекомых» демонстрирует мозаичную цельность охвата всего комплекса актуализированных существующих или значимых мифов:

«В комнате было темно, пахло одеколоном, плесенью и потом. В центре размещался большой стол, покрытый клеенкой, рядом стояли кровать и тумбочка, на которой блестел ровный ряд граненых флаконов. На кровати, в ворохе скомканных простыней, лежало полуобнаженное тело, свесившее одну синюю трикотажную ногу к полу. Оно содрогалось в спазмах неспокойного сна и, естественно, не заметило появления на тумбочке недалеко от своей головы трех комаров. - Что это у него за татуировка? - тихо спросил Сэм, когда его глаза привыкли к полумраку. Ну, Ленин и Сталин - это понятно, а почему снизу написано «лорд»? Это что, местный аристократ? - Нет, - ответил Артур. - Это аббревиатура. «Лягавым. отомстят родные дети.» - Он ненавидит собак? - Понимаете, - снисходительно ответил Арнольд, - это сложный культурный пласт. Если я сейчас начну давать объяснения, мы буквально утонем. Давайте лучше, раз уж прилетели, брать пробу, пока материал спит. - Да-да, - сказал Сэм. - Вы совершенно правы. Он взмыл в воздух и после грациозного иммельмана над лежащим приземлился на участок тонкой и нежной кожи возле уха» (Пелевин, 2, 24).

Миф о светлом будущем дается в симулятивном ключе, обнаруживая свою знаковую природу, лишенную сакрального наполнения: таково стремление насекомых к свету или их человеческих проекций к лучшей жизни, но это, увы, недостижимо. Автор показал это в произведении «Жизнь насекомых» таким образом:

«- Но ведь есть же права насекомых, наконец... - Какие там права, - махнула лапкой Наташа. - А ты знаешь, что такое цианамид кальция? Двести грамм на коровник? Или когда в закрытом навозохранилище распыляют железный купорос, а улететь уже поздно? У меня две подруги так погибли. А третью, Машеньку, хлористой известью залили. С вертолета. Французский учила, дура... Права насекомых, говоришь? А про серно-карболовую смесь слышал? Одна часть неочищенной серной кислоты на три части сырой карболки -вот и все наши права. Никаких прав ни у кого тут не было никогда и не будет, просто этим, - Наташа кивнула вверх, валюта нужна. На теннисные ракетки и колготки для жен. Сэм, здесь страшно жить, 
понимаешь? Сэм погладил Наташину голову, поглядел на украшенный плакатом холодильник и вспомнил Сильвестра Стэллона, уже раздетого неумолимым стечением обстоятельств до маленькихплавок, и оказавшегося на берегу желтоватой вьетнамской реки рядом с вооруженной косоглазой девушкой. «Ты возьмешь меня с собой?» - спросила та. - Ты возьмешь меня с собой? - спросила Наташа. Рэмбо секунду подумал. «Возьму,» - сказал Рэмбо. Сэм секунду подумал. - Видишь ли, Наташа, - начал он, и вдруг оглушительно чихнул» (Пелевин, 2, 193).

Так, по мнению С. Некрасова, «Жизнь насекомых» - это своеобразный перифраз «Божественной комедии» Данте, в которой советская действительность оказывается при этом своеобразным вариантом ада, где в качестве адских мук фигурирует безысходное переживание специфических состояний ума (Некрасов 19).

Пелевин постоянно использует в своих романах поэтику мифологизирования как циклическую ритуально-мифологическую повторяемость для выражения универсальных архетипов и для конструирования самого повествования так же, как и концепцию легко сменяемых социальных ролей (масок), подчеркивающих взаимозаменяемость, «текучесть» персонажей (Чапаев - и начдив, и белый офицер, и гуру; Петька - и ординарец, и поэт-декадент, и пациент психбольницы; Котовский - и олигарх, и красный командир, и адепт; Фурманов - и вождь ткачей, и представитель красного Хаоса и т.д.).

Элементы текстов романов «Омон Ра», «Жизнь насекомых», «Чапаев и Пустота», «Generation „П“», «Священная книга оборотня» взаимодействуют не только с отдельными мифами, но и с их общностями, в том числе выявленными непосредственно автором. Так, в романе «Омон Ра» место архаичного мифа занимает советский миф, в роли традиционного мотива выступает характерная для советской культуры мифологема жертвенности индивидуума как члена социума. Роман «Чапаев и Пустота» построен на взаимодействиях героя и его трикстеров, которые передают герою знание о мире. В романе же «Generation „П“» развивается мотив испытания героя, для создания космоса романа привлекается шумеро-аккадская мифология.

Повествователь у Пелевина структурирует модель сознания, которая конструирует окружающий мир по-своему с помощью воспринятых и переработанных мифологем, принимая его как единственно реально существующий, причем таких моделей автор может эксплицировать несколько. Герои, несущие в себе данную модель, рефлексируют по поводу своего положения, некоторые оказываются способными вырваться из сансары существования в замкнутом мире окружающих их мифологем.

«Земля, вдруг понял я. Я вышел из закутка под лестницей и медленно побрел по платформе к большому зеркалу в ее конце. Над зеркалом мигали грозные 
оранжевые знаки времени, сообщавшие, что еще не вечер, но времени уже довольно много, а последний поезд прошел чуть больше четырех минут назад. Из зеркала на меня посмотрел молодой человек с очень давно не бритой щетиной, его глаза были воспалены, а волосы сильно всклокочены. Одет он был в грязный черный ватник, в нескольких местах вымазанный побелкой, и имел такой вид, словно спал последней ночью черт знает где. Впрочем, именно так оно и было. На меня начинал посматривать прохаживающийся по залу милиционер с маленькими темными усами, и когда подошел поезд, я без особых колебаний шагнул в раскрывшуюся дверь. Она закрылась, и поезд повез меня в новую жизнь. Полет продолжается, подумал я. Половина лампочек в луноходе не горела, и свет от этого казался каким-то прокисшим. Я уселся на лавку, сидевшая рядом женщина рефлекторно сжала ноги, отодвинулась и поставила в освободившееся между нами пространство сетку с продуктами - там было несколько пачек риса, упаковка макаронных звездочек и мороженая курица в целлофановом мешке. Однако надо было решать, куда ехать. Я поднял глаза на схему маршрутов, висящую на стене рядом со стоп-краном, и стал смотреть, где именно на красной линии я нахожусь» (Пелевин, 3, 227).

Автор считает возможным наличие личности у героя, чье сознание полностью свободно от мифологем. Отличие протагониста романа «Омон Ра» от такого героя подчеркивается ироничной автоцитацией: персонаж одной из глав романа «Жизнь насекомых», личинка цикады, повторяет путь Омона через путешествие под землей с финальной догадкой о возможности полета, стоит только выбраться на поверхность (стать цикадой).

Однако даже приобретя физическое освобождение, персонажи почти неосознанно испытывают сомнение в окончательности освобождения. Герой нескольких глав, передающих центральную сюжетную линию, мотылек Митя, сначала повторяет путь, предназначенный всем насекомым: становясь светлячком, но через общение с альтер эго, хранителем дхармы, прозревает и становится выше любой мифологизации.

«Митя лежал в полутьме, задрав ноги в кроссовках на высокую решетчатую спинку кровати, и поглаживал рукой Марка Аврелия Антонина, сплющенного веками в небольшой зеленый параллелепипед, листать который было уже темно. Рядом лежала другая книга, китайская, называвшаяся «Вечерние беседы комаров У и Цэ». Вот смотри, - сказал Митя, - ты говоришь - тьма. Я сегодня вечером взлетел действительно, тьма. А на танцплощадке народ, все смеются, танцуют, и песня играет, вот как сейчас. Глупая страшно... Я тебе даже так скажу, - с горячностью продолжал Митя, - если самый главный ленинградский сверчок возьмет лучшую шотландскую волынку и споет под нее весь «Дао дэ цзин», он и на сантиметр не приблизится к тому, во что эти вот идиоты, - Митя кивнул в сторону, откуда доносилась музыка, - почти попадают. - Да во что попадают? - Не знаю, - сказал 
Митя. - Как будто раныше было в жизни что-то бесценное, а потом исчезло, и только тогда стало понятно, что оно было. И оказалось, что абсолютно все, чего хотелось когда-то раньше, имело смысл только потому, что было это, непонятное. А без него уже ничего не нужно. И даже сказать про это нельзя. Ты знаешь, до какого огня я действительно хотел бы долететь? Было такое стихотворение, вот послушай: «Не жизни жаль с томительным дыханьем, что жизнь и смерть? А жаль того огня, что просиял над целым мирозданьем, и в ночь идет, и плачет, уходя...». Ведь летели-то они все на свет. А как ни летай, светится только танцплощадка. И получается, что все вроде бы летят к жизни, а находят смерть. То есть в каждый конкретный момент движутся к свету, а попадают во тьму. Знаешь, если бы я писал роман о насекомых, я бы так и изобразил их жизнь - какой-нибудь поселок у моря, темнота, и в этой темноте горит несколько электрических лампочек, а под ними отвратительные танцы. И все на этот свет летят, потому что ничего больше нет». (Пелевин, 2, 140).

В этом романе также заметна очевидная ориентированность писателя на буддийский способ миропостижения и философствования. Автор опирается на одно из понятий в индийской философии - дхарма.

«Дхарма (санскр. dharma, пали dhamma) - одно из важнейших понятий всей индийской мысли, в самом общем виде означающее «порядок», «парадигму», «норму» существования и развития как космоса, так и общества; регулятивный духовный, социальный и нравственный «закон». Объем понятия «дхарма» включает, т.о., значения и «религии», и «права», и «морали». Дхарме наиболее близки понятия «правды» (сатья), «заслуги» (пунья) и «блага» (кушала)» (Философская энциклопедия 1)

Из парадигмы «пути», сходной с буддистской, пути к духовному просветлению, через поиск и сомнение, порождается та усовершенствованная концепция мира и человека, которая также эксплицируется в романе «Чапаев и Пустота». Предметный мир Пелевина оказывается, с одной стороны, опирающимся на мотивы архаических мифов о культурном герое, а с другой - на преобразование мифа о Василии Ивановиче Чапаеве. Как бы попутно, широко иллюстрируются современные автору метарассказы, придающие роману репрезентативность по отношению к обобщенной картине сознания, однако претензии на абсолютную аутентичность, сходные с тенденциями, имевшими место в случае с «Жизнью насекомых», тут явно отсутствуют.

То, что в романе «Чапаев и Пустота» было определено как «пустота», тождественная фамилии главного героя и картине мира отдельно взятого сознания, оказывается присутствующим в космосе романа “Generation „П“». Читатель может увидеть ироническую «автоинтертекстуальность» в системе образов романа; дух Че Гевары развертывает откровенное позиционирование 
«антимифологизаторских» идей, одной из которых является отождествление названного индивидуального сознания с пустотой, стоящей на порядок выше пустоты, существовавшей до внедрения современных информационных технологий.

До сих пор субъект мифологизации (не отождествляемый в романе «Омон Ра» с советским государством, в «Жизни насекомых» со зловещим пнем «южного дерева чикле», в «Чапаеве и Пустоте» с Григорием Котовским) приобретает в романе «Generation „П“» свое место в системе образов. Транслятор тотального мифа обладает множеством имен и характеристик - для духа Че Гевары это объективированный масс-медиа виртуальный ORANUS, для безымянного автора цитируемого труда по шумеро-аккадской мифологии - божество Энкиду (Эпос о Гильгамеше).

Впервые у Пелевина целью главного героя становится самосовершенствование во имя достижения статуса управляющего субъектом мифологизаторства. Герой осознает иллюзорность того, что он ранее принимал за предсказуемую реальность. Так, для Вавилена Татарского это некий метафизический брак с богиней Иштар или занятие места бога Энду, сотворившего Энкиду. «Объективно» это оказывается тождественным занятию места главы могущественного учреждения, занимающегося одновременно производством рекламы и PR-oм, то есть фактически творящего реальность современного общества.

«Это тоже мифологема, - сказал Фарсейкин. - У великой богини был муж, тоже бог, самый главный из всех богов, которого она опоила любовным напитком, и он уснул в святилище на вершине своего зиккурата. А поскольку он был бог, то и сон у него такой, что... Ну, в общем, дело путаное, но весь наш мир со всеми нами и даже с этой богиней ему как бы снится. И великая богиня постоянно ищет того, кому она снится, потому что только через него она обретает свою жизнь. А поскольку найти его нельзя, у нее есть символический земной муж, которого она сама выбирает. На священном гадании в Атланте оракул предсказал, что у Иштар в нашей стране появится новый муж. С Азадовским у нас давно были проблемы, но вот Кто этот новый, мы долго понять не могли... По ритуалу ты становишься мужем великой богини только после того, как тебя оцифруют. Превратят, так сказать, в визуальный ряд. - И что, потом во все клипы ипередачи будут вставлять? Как Азадовского? - Это твоя главная сакральная функция. У богини действительно нет тела, но есть нечто, что заменяет ей тело. По своей телесной природе она является совокупностью всех использованных в рекламе образов. И раз она являет себя посредством визуального ряда, ты, чтобы стать богоподобным, тоже должен быть преображен. Тогда вы будете иметь возможность мистически слиться. Собственно, ее мужем станет именно твоя 3D-модель, а сам будешь как бы... регент, что ли. Иди сюда» (Пелевин, 5, 239). 
Интертекстуально заимствованные мифологемы, элементы их структур, комплексы, образующие современные мифы, используются автором для структурирования предметного мира с целью иллюстрировать своеобразие личности, чье сознание является носителем конкретной мифемы, либо ради саморазоблачения мифологемы как неадекватной той концепции реальности, которой придерживается автор. Неомифологемы и метарассказы способствуют облегчению восприятия каждого конкретного текста, перекликаясь с мифами, повлиявшими в свое время на сознание читателя, что осознается автором как возможный источник придания тексту определенной привлекательности и доступности читателю.

Можно отметить, что для текстов Пелевина характерно внимание к современным мифологическим структурам, к мифам вообще, используемым им при создании художественных текстов. Исследуя феномен массовой культуры, В.П. Шестаков указывает на ее роль в формировании у современного человека мифологических структур сознания. Рассуждая, в чем же популярность боевиков, вестернов, триллеров и подобных произведений, он утверждает, что

«... секрет популярности заключается в характере самого героя, в том, что он отвечает потребностям довольно широких слоев невзыскательной публики. В нем сконцентрированы и нашли олицетворение мечты, надежды, неосознанные побуждения людских масс. Иначе такой успех был бы немыслим» (Шестаков 131).

Вывод, к которому приходит Пелевин на данном этапе своего творчества, приближает его точку зрения к сформированным уже путем научной рефлексии концепциям отказа от антропоморфности как единственного пути освобождения от подверженности влиянию мифа, концепциям, в той или иной форме транслируемым различными теоретиками постмодернизма (от Ч. Дженкса до В. Курицына). При этом преодоление принадлежности к биологическому виду, очевидно, неосуществимое для автора, оборачивается стремлением навязывать мифологемы собственному имплицитному реципиенту. Позиционирование текста романа как наиболее желанного для потребителя становится целью, демонстрирующей сохранение активного отношения к действительности. Эти следы приверженности авангардной парадигме, при наличии намеренного многозвучия и осознании относительности любого знания об «объективной реальности», по-прежнему оставляют актуальной проблему определения творческого метода Пелевина как постмодернистского.

Как и многие писатели XX века, Пелевин обращается к содержанию мифов, их героям, сюжетам и идеям, используя скрытый и еще не реализованный потенциал мифологического мышления. Повторяя миф, реконструируя его, Пелевин воспроизводит и заново актуализирует фундаментальные осно- 
вы человеческого существования и бытия вообще. Автор обращается к форме романа-мифа как самой подходящей для собственного мифотворчества, разоблачая старые мифы, создавая новые и сталкивая их между собой. Так делали многие авторы мифологического романа в XX веке: Ф. Кафка, Дж. Джойс, Т. Манн, Г.Г. Маркес, Х. Борхес, Дж. Апдайк.

Подводя итог проделанному исследованию, мы приходим к ряду выводов. Виктор Пелевин в романах использует в качестве одной из характерных такую особенность своей поэтики, как «неомифологизм» - интертекстуальное заимствование тех или иных элементов архаических структур (на уровне мотивов, некоторых архетипических фигур) или более поздних, в том числе современных, мифов (или метарассказов).

Заимствование элементов мифологических структур приобретает у Пелевина характер интертекстуальности как приема. Автор использует их для структурирования своего предметного мира и системы образов романов, для характеристики персонажа как создателя нового мифа. Используя героя в разных ипостасях, он по новому создает мир и реальность, и миф по-новому находит отражение в произведениях автора; так, Петька появляется в романе в трех ипостасях: ординарец, поэт-декадент, пациент психбольницы. И в каждой ипостаси он по-своему раскрывает текст, сталкивая разные миры, тексты, мифы. Кроме того, привлечение некоторых мифологем призвано способствовать облегчению восприятия текста романа. Указанные мифологемы соотносятся с наиболее влиятельными из воспринятых в свое время имплицитным читателем, что используется автором для придания тексту определенной привлекательности.

Структуры, чья мифологическая природа намеренно актуализируется повествователем, обладают, в свою очередь, функцией разоблачения тех идеологических, философских, мировоззренческих систем, элементами которых они являются. Подобные системы эксплицируются как расходящиеся с точкой зрения повествователя, а значит, не претендующие на обладание окончательной истиной о природе объективной реальности и собственно человека, истиной, обнаружение которой имеет для Пелевина как автора принципиальное значение.

\section{БИБЛИОГРАФИЯ}

Бахтин, Михаил. Эстетика словесного творчества. Москва: Искусство, 1986.

Бубенцова, Елена. Мифологизм в западноевропейской митературе ХХ века. Могилев: МГУ им. А. Кулешова, 2002.

Джеймсон, Фредерик. The Political Unconscious: Narrative as a Socially Symbolic Act. Ithaca, N.Y.: Cornell University Press, 1981. 
Земсков, Валерий. «Мифосознание в кризисную эпоху». Вопросы литературы, 3 (199), С. 32.

Лиотар, Жан-Франсуа «The Postmodern Condition: A Report on Knowledge». Theory and History of Literature, 10 (1984), p. 7.

Лосев, Алексей. Миф. Число. Сущность. Москва: Мысль, 1994.

Мелетинский, Елеазар. «Мифр и двадиуатый Век». 1994.

Мелетинский Елеазар. Поэтика мифа. Москва: Восточная литература, 2000.

Веб. 10/03/2018. http://www.ruthenia.ru/folklore/meletinsky1.htm

Некрасов, Сергей. Мечты, мечты, где ваша сладость? / / Библиография. 1999. №3. С. 65-76

Пелевин, Виктор (1). Омон Ра, Москва: Эксмо, 2013.

Пелевин, Виктор (2). Жизнь насекомых, Москва: Вагриус, 2000.

Пелевин, Виктор (3). Жёлтая стрела, Москва: Вагриус, 2000.

Пелевин, Виктор (4). Чапаев и Пустота, Москва: Вагриус, 2001.

Пелевин, Виктор (5). «Generation „П“», Москва: Вагриус,2008.

Рокотова, Наталия. Основы буддизма / Наталия Рокотова Е. И. Рерих. Улан-Удэ: Бурят, кн. изд-во, 1991. - 80c.

Савельева, Ирина. «Миф и его роль в мировоззрении и культуре». Журнальный клуб Интелрос «Credo New» 2 (2009). С. 1.

Смирнов, Игорь. «Реализм: диахронический подход». Russian Literature, 8 (1980). С. 1-2.

Солкин, Виктор. Древний Египет Энциклопедия, Москва: АРТ-родник, 2008.

Сорокина, Галина. «Буддийские коннотации в повести В. Пелевина «Желтая стрела». Литература ХХ века: итоги и перспективы изучения. Материалы пятых Андреевских чтений, Москва: Экон-Информ, 2007.

Стеблин-Каменский Михаил. Миф. Ленинград: Наука, 1976.

Веб. 19/12/2018. https:/ / norse.ulver.com/articles/steblink/myth/fr1.html

Топоров, Владимир. Пространство и текст. Текст: семантика и структура. Москва: Наука, 1983.

Философская энциилопедия Веб. 19/12/2018. https:/ / dic.academic.ru/dic.nsf/enc_philosophy

Цыганов А. Мифология и роман Пелевина «Чапаев и Пустота». 2003.

Веб. 10/03/2018. <http://www.pelevin.nov.ru/stati/o-myths/1.html>

Шестаков, Вячеслав. Мифология ХХ Века (критика теории и практики буржуазной массовой культуры),

Москва: Искусство, 1988.

Юнг, Карл. Душа и миф: Шесть архетипов. Санкт-Петербург: Питер, 2016.

Ян де Фрис. Forschungsgeschichte der Mythologie, München: Alber Karl, 1985. 